\title{
Fditorial
}

\section{Global viral hepatitis elimination by the year 2030}

\author{
Richard Tjan \\ Editor
}

According to a report by Stanaway et al. ${ }^{(1)}$ in 2016, the absolute burden and relative rank of viral hepatitis increased between 1990 and 2013. For example, the number of global deaths due to viral hepatitis increased from 0.89 million to 1.45 million, indicating a need for its reduction. In this connection, on 28 May 2016 the $69^{\text {th }}$ World Health Assembly adopted the global health sector strategy on viral hepatitis for the period 2016-2021, ${ }^{(2)}$ as outlined in the report A69/32 of the Secretariat, ${ }^{(3)}$ with the goal of eliminating viral hepatitis B and $\mathrm{C}$ by the year 2030. The global health sector strategy (GHSS) on viral hepatitis has constructed a roadmap toward the elimination of viral hepatitis $\mathrm{B}$ and $\mathrm{C}$, targeting five priority prevention and treatment interventions. Prevention involves universal hepatitis B immunization of infants, prevention of mother-to-child transmission, increased injection safety and blood safety, and increased harm reduction, the implementation of which will contribute toward universal health coverage, which is the target for Goal 3 of the 2030 Agenda for Sustainable Development. In combination with treatment of chronic hepatitis, the goal is to achieve by the year 2030 a reduction in the incidence of viral hepatitis by $90 \%$ and mortality by $65 \%$. $^{(3,4)}$

It is common public health knowledge that elimination and/or eradication of a communicable disease is governed by a number of factors related to the agent, host and environment. When the agent attacks only humans and when vaccines and/or treatments are available, the limiting factors are usually economic and political. This should also apply to the proposed viral hepatitis elimination program. However, since this program is still in its early stages, this editorial will focus on a comparison with the historically successful smallpox eradication program.

Since the success of the smallpox eradication program, the WHO has gathered valuable data and experience about infectious disease elimination/eradication programs. Smallpox eradication was facilitated by the absence of an intermediate host or animal reservoir and of a carrier state. On the negative side, there was no virocidal drug against smallpox. Eradication of smallpox was mainly achieved by active surveillance and rapid containment, replacing mass vaccination as the priority approach, in combination with political support and dedicated manpower.

Smallpox was officially declared eradicated in 1980 and was the first viral infectious to have been combated successfully through international cooperation on a global scale, leading to its demise. In the 1960s, the disease was still endemic in Africa and Asia. The disease was conquered through vaccination campaigns, surveillance and prevention measures. Before 1967, the smallpox eradication strategy relied on mass vaccination, which was however ineffective in densely populated regions where containment measures proved more effective, so as to relegate mass vaccination to a secondary role. The experience gained was helpful in formulating other control, elimination and/or eradication programs. To quote the 2010 the $\mathrm{WHO}$ in commemorating the $30^{\text {th }}$ 
anniversary of smallpox eradication: "The eradication of smallpox shows that with strong mutual resolve, teamwork and an international spirit of solidarity, ambitious global public health goals can be attained."(5)

It may or may not be coincidence that the smallpox eradication program came in the wake of an unsuccessful malaria eradication program (although at that time no malaria vaccine was available), while the 2016 hepatitis elimination program comes after the 2015 malaria elimination program. Hopefully both programs will achieve their goals within the targeted time.

As was the case with smallpox, viral hepatitis $\mathrm{B}$ and $\mathrm{C}$ are limited to humans only, but a problem in their elimination is the presence of a carrier state. However, one favorable point is the availability of drugs for the treatment of chronic viral hepatitis, with the prospect of reduced prices in the near future. ${ }^{(6)}$

Globally, immunization for the prevention of viral hepatitis B has achieved considerable success. In addition to the well-established hepatitis A and B vaccines developed more than 20 years ago, only recently a vaccine for hepatitis $\mathrm{E}$ has become available, although not on a wide scale. $^{(1)}$

In 2010, Indonesia, Brazil, and Columbia proposed a global comprehensive viral hepatitis prevention and management program, with the WHO providing assistance in the development of national strategies, effective surveillance, vaccine development, and treatment. ${ }^{(7)}$

By the end of 2014, the number of children worldwide who received three doses of hepatitis B-containing vaccine was around $80 \%$. The vaccine is available in combination with other vaccines in the Expanded Programme on Immunization (EPI), and has been reported to be highly effective, inexpensive, and highly costeffective. ${ }^{(5)}$ The Indonesian immunization program has been compulsory for each infant (aged 0-11 months) to receive complete basic immunization, including hepatitis B vaccination. During the last 9 years the hepatitis B immunization coverage had always remained above $90 \%$, while according to three Indonesian Basic Health surveys the coverage ranged from $62 \%$ to $76 \%$.(7)

Since effective oral medicines are available for the treatment of chronic hepatitis B in persons born before hepatitis $\mathrm{B}$ vaccines became available, elimination of hepatitis B is now possible. Since no hepatitis $C$ vaccine is in existence, treatment with oral medicines will be used for its elimination. ${ }^{(5)}$

In April 2016, the Indonesian Ministry of Health has set out the outlines of a program to eliminate mother-to-child hepatitis B transmission by the year 2020, along with HIV and syphilis and of a hepatitis $\mathrm{C}$ elimination program by 2030. ${ }^{(9)}$

After the implementation of mass vaccination and treatment, combined with surveillance and containment, the next step is monitoring, evaluating and reporting the results, thus providing the necessary feedback to the program directors. Here the completeness and reliability of the reports are essential. In the case of hepatitis virus $\mathrm{C}$ infections, even in the US statistical data on HCV disease are incomplete. According to the Chronic Hepatitis Cohort Study $(\mathrm{CHeCS})$ conducted at four US healthcare systems, HCV infection is greatly underdocumented on death certificates, since only $19 \%$ of all $\mathrm{CHeCS}$ decedents and only $30 \%$ of those with recorded liver disease had HCV listed on their death certificates. ${ }^{(10)}$

Overall, the prospect of a successful outcome of the proposed viral hepatitis elimination program seems to be relatively good, although the GHSS is of the opinion that "elimination of viral hepatitis epidemics will require new technologies and approaches", since the existing medicines, technologies and service delivery approaches are likely to be inadequate to achieve the 2030 targets. ${ }^{(4)}$ The main obstacle will presumably be economic, ${ }^{(1)}$ especially in developing countries with multiple concurrent elimination programs (eg. malaria and viral hepatitis) in progress. These may require considerable outside financial assistance, although the GHSS stresses national funding. ${ }^{(4)}$ 


\section{REFERENCES}

1. Stanaway JD, Flaxman AD, Naghavi M, et al. The global burden of viral hepatitis from 1990 to 2013: findings from the Global Burden of Disease Study 2013. Lancet 2016. DOI: http:// dx.doi.org/10.1016/S0140-6736(16)30579-7.

2. Sixty-ninth World Health Assembly. Global health sector strategies on HIV, viral hepatitis and sexually transmitted infections, for the period 2016-2021. Resolution WHA69.22. Geneva: World Health Organization;2016.

3. Sixty-ninth World Health Assembly. Draft global health sector strategies - viral hepatitis, 20162021. Report by the Secretariat.A69/32. Geneva: World Health Organizationl;2016.

4. World Health Organization. Global health sector strategy on viral hepatitis 2016-2021: towards ending viral hepatitis. WHO/HIV/2016.06. Geneva: World Health Organization;2016.

5. World Health Organization advocacy brief. Combating hepatitis $\mathrm{B}$ and $\mathrm{C}$ to reach elimination by 2030. Geneva: World Health Organization;2016.
6. World Health Organization. The smallpox eradication programme - SEP (1966-1980). Geneva: World Health Organization;2010.

7. Direktorat Jenderal Pengendalian Penyakit dan Penyehatan Lingkungan, Kementerian Kesehatan RI. Pedoman pengendalian hepatitis virus. Jakarta : Direktorat Jenderal Pengendalian Penyakit dan Penyehatan Lingkungan, Kementerian Kesehatan RI;2012.

8. Info Datin Kementerian Kesehatan RI;2016. Situasi imunisasi di Indonesia. Jakarta: Pusat Data dan Informasi, Kementerian Kesehatan RI;2016.

9. Biro Komunikasi dan Pelayanan Masyarakat, Kementerian Kesehatan RI. Sebagian besar kematian akibat hepatitis virus berhubungan dengan hepatitis B dan C kronis. Jakarta: Biro Komunikasi dan Pelayanan Masyarakat, Kementerian Kesehatan RI; 2016.

10. Mahajan R, Xing J, Liu SJ, et al. for the Chronic Hepatitis Cohort Study (CHeCS) investigators. Mortality among persons in care with hepatitis $C$ virus infection: the Chronic Hepatitis Cohort Study (CHeCS), 2006-2010. Clin Infect Dis 2014;58:1055-61. 